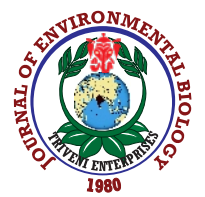

\title{
Effects of heavy metals on Antarctic bacterial cell growth kinetics and degradation of waste canola oil
}

\author{
K.N.M. Zahri', A. Zulkharnain'2 , C. Gomez-Fuentes ${ }^{3}$, S. Sabri' and S.A. Ahmad ${ }^{1,5 *}$ \\ 'Department of Biochemistry, Faculty of Biotechnology and Biomolecular Sciences, Universiti Putra Malaysia, 43400 UPM Serdang, Selangor, Malaysia \\ ${ }^{2}$ Department of Bioscience and Engineering, College of Systems Engineering and Science, Shibaura Institute of Technology, 307 Fukasaku, Minuma- \\ ku, Saitama, 337 8570, Japan \\ ${ }^{3}$ Department of Chemical Engineering, Universidad de Magallanes, Avda. Bulnes, 01855, PuntaArenas, Región de Magallanes yAntártica Chilena, Chile \\ ${ }^{4}$ Department of Microbiology, Faculty of Biotechnology and Biomolecular Sciences, Universiti Putra Malaysia, 43400 UPM Serdang, Selangor, Malaysia \\ ${ }^{5}$ National Antarctic Research Centre, B303 Level 3, Block B, IPS Building, Universiti Malaya, 50603 Kuala Lumpur, Malaysia \\ *Corresponding Author Email : aqlima@upm.edu.my
}

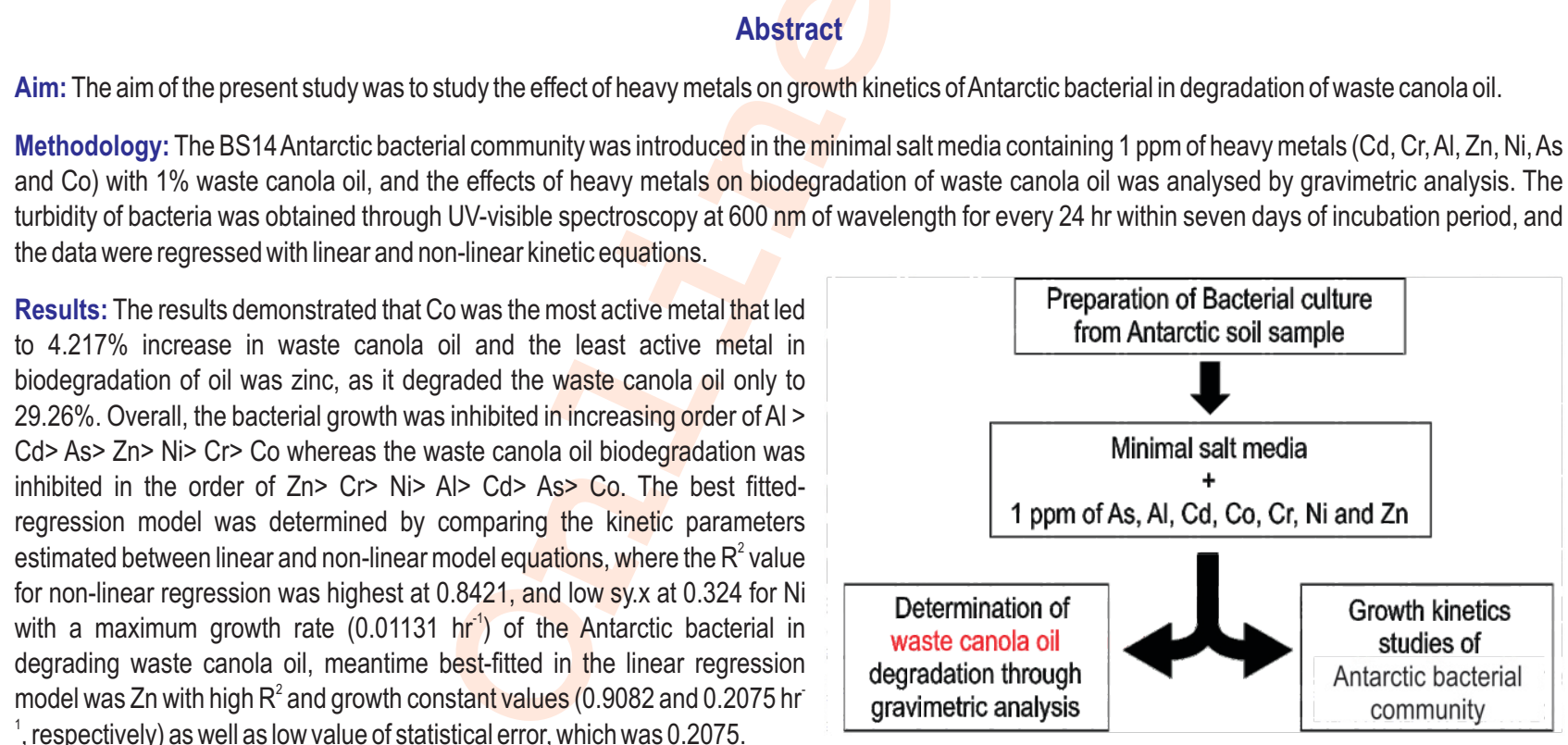

Interpretation: The presence of heavy metals in Antarctic bacterial community could suppress the ability of bacteria to degrade waste canola oil, and this can slower the rate of bacterial growth in the kinetics studies. Hence, this work would be helpful in actual bioremediation operations by understanding and manipulating the process of the kinetics parameters.

Key words: Antarctic, Canola oil, Degradation, Heavy metal, Kinetic growth

How to cite : Zahri, K.N.M., A. Zulkharnain, C. Gomez-Fuentes, S. Sabri and S.A. Ahmad: Effects of heavy metals on Antarctic bacteria cell growth kinetics and degradation of waste canola oil. J. Environ. Biol., 41, 1433-1441 (2020). 


\section{Introduction}

Canola oil is used most in the station base in Antarctica for food preparation, including butter and margarine (Zahri et al., 2020). Globally, grease and oil are discharged directly from the kitchens, restaurants and food industries, including the waste cooking oil, which can have serious environmental consequences due to their properties that are similar to those of petroleum-based oils (Garcia-Dávila et al., 2017). The oil spillage is one of the biggest issues in Antarctica, together with cooking oil pollution that also could contribute to this issue since both of them are categorised as hydrocarbons. At the same time, oil pollution can affect the environmental ecosystems in Antarctica,including animals (penguins, seal, fish, birds) and humans. Oil can also cause mechanical injuries such as loss of insulation, mobility and smothering (Department of Ecology, 2016). Waste canola oil can be toxic to organisms if the oil is repeatedly heated for cooking, which can lead to the formation of acrolein with thermal oxidation (Falade et al., 2017) known as a precursor to carcinogen (Henning et al., 2017).

Microbial communities were used directly from the Antarctic soils to degrade the waste canola oil, by reason that the introduction of non-native microorganisms is not permitted according to the Antarctic treaty norms (Hughes et al., 2020). In the bioremediation process, the microorganisms can be affected due to the presence of any other pollution or natural compounds present in that particular area (Martínez-Prado and Soto-Álvarez, 2017). In Antarctica, the presence of heavy metals by natural sources and anthropogenic activity (Chu et al., 2019) needs to be considered for degrading oil. Exposure to heavy metals creates a stress condition for bacteria and disrupts their metabolic reactions; therefore, this can be a major challenge for bioremediation of pollutants including waste canola oil. Earlier studies have reported the presence of heavy metals in the soils, marine, snow and Antarctic ice, which were contributed from natural sources, local contamination and anthropogenic activities including cadmium, zinc, aluminium, arsenic, chromium, nickel and cobalt (Neto et al., 2017; Chu et al., 2019). Some of the psychrophilic and psychrotolerant bacteria genera such as Rhodococcus, Pseudomonas, Acinetobacter, Sphingomonas and Arthrobacter are the microbial community commonly isolated from the Antarctic pristine for degrading the hydrocarbons (Aislabie et al., 2001; Ruberto et al., 2005; Roslee et al., 2019).

The growth rate of microbial community is one of the key players in degrading waste canola oil in the presence of heavy metals. Heavy metals can be inhibitory or stimulatory for growth depending on the protection mechanisms of heavy metal resistance by microbial cells (Inigiri et al., 2018). Abatenh et al. (2017) stated that metal ion has a direct and indirect impact on the rate of degradation, where the degree and mechanism of toxicity of different type of metals are vary with specific toxicants and exposed microorganisms. Some metals are essential for bacteria for redox processes; these include $\mathrm{Co}, \mathrm{Cu}$ and Ni. Nevertheless, most of them are non-essential, which have no nutrient value and potentially toxic to microorganisms (Bruins et al., 2000). Toxicity of heavy metals require various mechanisms, which can cause sever fatal enzymatic functions, generate reactive oxygen species, destroying ion regulation, and directly manipulate DNA and protein formation (Inigiri et al., 2018). For example, heavy metals like lead disturb most microbial metabolism and activities, including membrane transport, respiration and ribosome activity; yet, in certain circumstances, these heavy metals can lead to cell death (Murthy et al., 2013).

To predict and estimate the biodegradation efficiency, scientists have developed mathematical models for bacterial growth and decay as well as for the substrate and electron acceptor utilisation (Kim et al., 2005). Various models have been established for the kinetics of microbial growth, which generate several important kinetics parameters for analysis. Moreover, kinetic studies provide a strategy for solving problems of the real application in the industrial scale, including bioremediation operations (Gupta and Yadav, 2017). Keeping in view the above the aim of this study was to investigate the bacterial community growth and degradation of waste canola oil in presence of heavy metals by evaluating and comparing linear and exponential growth curves.

\section{Materials and Methods}

Sample collection: Soil samples for isolation of bacterial strains and waste canola oil samples were collected from the research station in Antarctica (Base General Bernardo O'Higgins Riquelme). The samples were stored appropriately in EcoRemediation Technology Laboratory, Universiti Putra Malaysia until further analysis.

Preparation of bacteria culture: Bacteria from soil samples were cultured in sterile nutrient broth for four days on a $150 \mathrm{rpm}$ orbital shaker at $10^{\circ} \mathrm{C}$. The bacterial culture was transferred to $50 \mathrm{ml}$ of nutrient broth and left for shaking on an orbital shaker for another four days. This step was used as a pre-enrichment of bacteria by growing the bacteria in nutrient broth several times and eliminating the solid soil particles. The bacterial community was prepared for glycerol stock and stored at $-80^{\circ} \mathrm{C}$ for long term storage.

Enrichment of waste canola oil utilising bacteria community with heavy metals: The bacteria were cultured from the stock into nutrient broth and incubated for two days on an orbital shaker at $10^{\circ} \mathrm{C}$. One milliliter of bacteria from nutrient broth was added to $50 \mathrm{ml}$ of modified minimal salt media; consisting $\mathrm{K}_{2} \mathrm{HPO}_{4}(4.74 \mathrm{~g})$, $\mathrm{KH}_{2} \mathrm{PO}_{4}(0.56 \mathrm{~g}),\left(\mathrm{NH}_{4}\right)_{2} \mathrm{SO}_{4}(0.5 \mathrm{~g}), \mathrm{MgSO}_{4} .7 \mathrm{H}_{2} \mathrm{O}(0.5 \mathrm{~g})$ and $\mathrm{CaCl}_{2} .2 \mathrm{H}_{2} \mathrm{O}(0.1 \mathrm{~g})$ per $\mathrm{L}$ (Ibrahim et al., 2020) and the medium was adjusted with $\mathrm{HCl}$ to $\mathrm{pH} 7$. All flasks were supplemented with $1 \mathrm{ppm}$ of different types of heavy metals and $1 \%$ of sterilised waste canola oil(filtered using a $0.45 \mu \mathrm{m}$ filter membrane). All flasks were incubated at $10^{\circ} \mathrm{C}$ on $150 \mathrm{rpm}$ orbital shaker for seven days. The experiment was conducted in triplicate. The bacterial community growth was recorded every day with a spectrophotometer $\left(\mathrm{OD}_{600 \mathrm{~mm}}\right)$ and the data were further used for 
growth kinetic studies. On the other hand, degradation of waste canola oil was determined gravimetrically by measuring the oil mass. After seven days incubation, $n$-hexane solvent was added to the media (1:1 ratio) and the flasks were shaken vigorously (Brooksbank et al., 2007), allowing the mixture of oil and media to separate into two layers by dissolving the oil with the solvent for $20 \mathrm{~min}$ at room temperature. The organic phase was extracted into a petri dish,while oil reduction was determined by the weight of the oil, reflecting the amount of waste canola oil (Ibrahim et al., 2020). The pre-weighed petri dishes containing the solvent were left overnight in the fume hood to allow complete evaporation of the solvent. The volume of extracted crude waste canola oil was deducted from petri dish and the degradation percent was calculated by the formula:

$$
\text { Degradation }(\%)=\frac{\text { Amount of crude oil degraded }}{\text { Amount of crude oil added in the media }} \times 100
$$

Kinetic growth curve: Non-linear regression was selected as it is more general and can be utilised to estimate model parameters. Bacteria grow exponentially, and the optical density $(O D)$ increases as a function of In (OD). The growth rate is the change in the number of cells per minute that estimates the change in OD per min (Hall et al., 2003). The growth measurement assessed the cell density at a series of seven time points (seven days) spectrophotometrically and measured the turbidity of cells, in terms of optical density. This growth curve was assessed using the exponential growth equation (curve fit) by statistical software of GraphPad Prism software (Version 7). At the same time, the linear regression curve was analysed to identify the differences between these two models.

Statistical analyses: Statistical analysis was carried out with SPSS software version 22 through One-way analysis of variance (ANOVA) where all the experiments were completed in triplicate. $95 \%$ confidence level was used to evaluate differences between group with $p<0.05$ considered as statistically significant. The data acquired are presented as mean \pm standard error.

\section{Results and Discussion}

Based on Fig. 1, the bacterial growth was inhibited in the increasing order of $\mathrm{Al}>\mathrm{Cd}>\mathrm{As}>\mathrm{Zn}>\mathrm{Ni}>\mathrm{Cr}>\mathrm{Co}$. 1 ppm of $\mathrm{Al}$ could inhibit bacterial growth as compared to other heavy metals. The lowest turbidity of bacteria in the media containing Al was at $1.672 \mathrm{~nm}$; as a result, Al can become toxic to microorganisms and plants at low pH. Similarly, Kurniawan et al. (2018) stated that Al was able to decrease bacterial growth rate by adjusting or inhibiting some enzymatic reactions (especially disrupt membranes). This is in agreement with the study of (Purwanti et al., 2018) who reported that the growth of Vibrio alginolyticus inhibited at 100 to $350 \mathrm{mg} \mathrm{l}^{-1}$ of Al concentration.

Cd demonstrated high bacterial growth $(1.689 \mathrm{~nm})$, which was slightly higher than $\mathrm{Al}$; however, there were no significant differences between these two conditions ( $p>0.05$ ). Cd suppressed the Antarctic bacteria community, which might occur due to the properties of this metal that could alter the protein expression in bacterial cells. This is important for determining the number of growth factors and other protein (Abbas et al., 2014a). treated Pseudomonas strain RZCD with different concentrations of $\mathrm{Cd}$ (50 to $550 \mu \mathrm{g} \mathrm{ml}^{-1}$ ) and observed the at $400 \mu \mathrm{g} \mathrm{ml}^{-1} \mathrm{Cd}$ the bacterial growth started to decrease rapidly as bacterial cells could not resist the interference of $\mathrm{Cd}$ at that particular concentration. Similarly, arsenic also showed low turbidity cell growth due to the interference of proteins in the bacterial metabolism responsible for phosphate uptake and transport, since this metal acts a phosphate analogue (Pandey et al., 2011).

Generally, bacterial growth is concomitant and proportional to the degradation of pollutants as pollutants itself (such as hydrocarbons serves as carbon source) act as nutrient for bacterial growth (Al-Hadithi et al., 2017; Samimi and Moghadam, 2020). However, in this study, the effect of heavy metals on the bacterial community exhibited different conditions for the growth and degradation of waste canola oil. Viewing at waste canola oil degradation, inhibition increased in the following order: $\mathrm{Zn}>\mathrm{Cr}>\mathrm{Ni}>\mathrm{Al}>\mathrm{Cd}>\mathrm{As}>\mathrm{Co}$ (Fig. 1). Antarctic bacterial community degraded a minimum of $29.26 \%$ of waste canola oil in the media comprising $\mathrm{Zn}$ metal. This was followed by $31.07 \%$ in $\mathrm{Cr}$, $32.19 \%$ in Ni, $35.11 \%$ in Al, 36.49\% in Cd, $37.01 \%$ As and maximum degradation at $53.18 \%$ in Co media. Although the media containing $\mathrm{Zn}, \mathrm{Cr}$ and $\mathrm{Ni}(\mathrm{p}<0.001)$ showed high bacterial growth, the rate of degradation was inhibited since these metals have altered the enzymatic function of the bacteria to breakdown the waste canola oil. The bacteria may survive in this condition because the survival of microbial depends on the inherent structural and biochemical properties. Although, this isolate involved different types of community bacterial where the possibilities for Rhodococcus, Pseudomonas and Arthrobacter Antarctic bacterial group are involved in hydrocarbons degradation as reported by several previous studies (Aislabie etal., 2001; Lee etal., 2018).

$\mathrm{Zn}$ is an essential trace element and acts as a catalytic or structural cofactor of enzymes and proteins involved in protein synthesis and DNA replication (Zakaria et al., 2020). However, excessive amount of $\mathrm{Zn}$ can be harmful to organisms. In this study, 1 ppm of $Z n$ hindered the degradation of waste canola oil where it was capable of inhibiting the enzyme activity through interaction with enzymes directly involved in biodegradation (Abdu et al., 2016). Low concentration of zinc ion reported to reduce biodegradation of crude oil by Pseudomonas sp. at 0.43 $\mathrm{mg} \mathrm{l}^{-1}$ and Micrococcus sp. at $0.46 \mathrm{mg} \mathrm{l}^{-1}$ (Sandrin and Maier, 2003). Nevertheless, strong inhibition of enzyme activity for degrading waste canola oil by heavy metals may occur (Malley et al., 2006; Karaca et al., 2010). Generally, heavy metals causetoxicity by relocating the essential metal ions from native binding sites, hindering the essential functional groups of protein, changing conformation of biological structure, disintegrating essential metabolites and osmotic balance around the cells arechange (Murthy et al., 2014). 


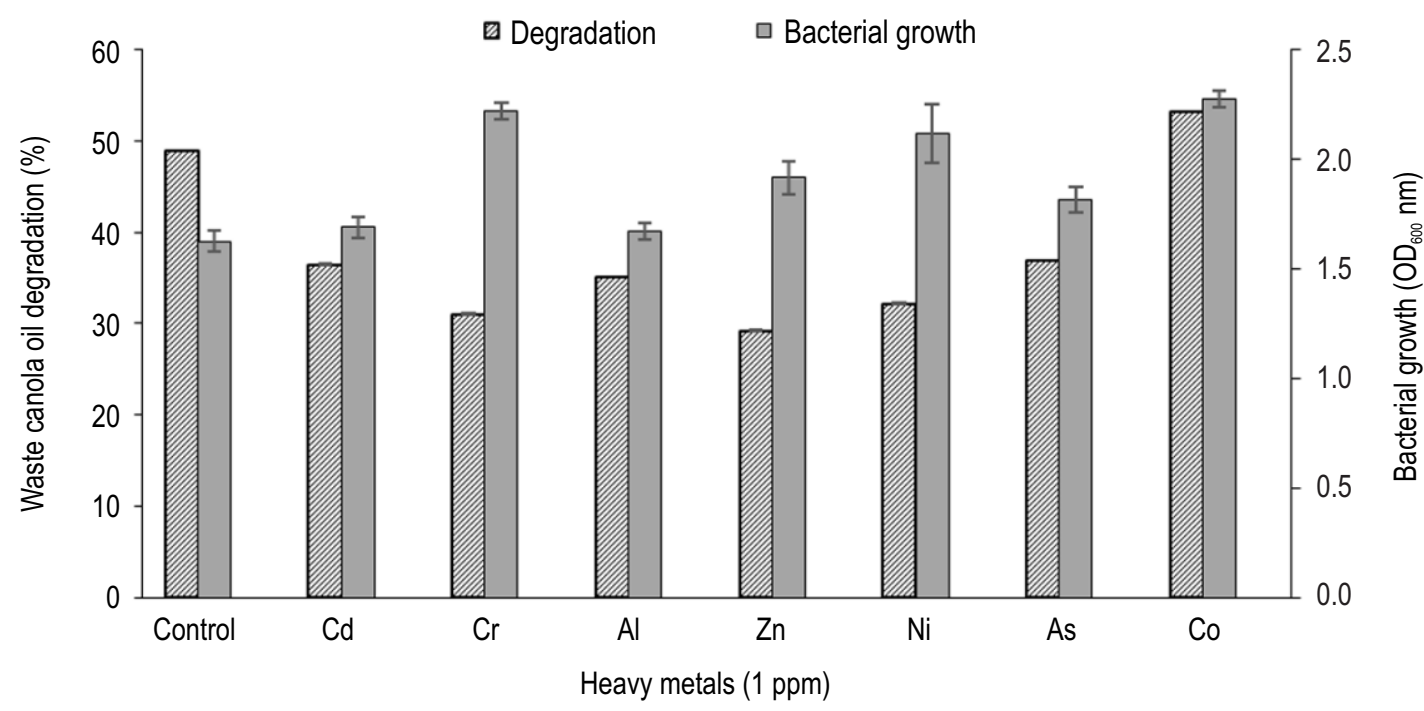

Fig. 1: Growth and waste canola oil degradation effect of various heavy metals (1 ppm) for 7 days. Control indicates no heavy metals. Data represent mean $\pm \operatorname{SEM}(n-3)$.

Nonetheless, bacteria can adopt different mechanisms to interact and survive in the presence of inorganic metals. Soil microbes have devised several mechanisms to combat and mitigate the effects of heavy metal toxicity on their survival (Abdu et al., 2016). As shown in Fig. 1, the ability of bacterial community to stand with the toxicity of heavy metals to degrade waste canola oil was found to decrease, except for Co that is known to be an essential trace element for bacterial growth. Degradation of waste canola oil on adding cobalt was found highest $(53.13 \%)$ which induced the degradation of waste canola oil as compared to the control $(p<0.001)$. Cobalt mainly occurs as cofactor B12 that plays an important role in the metabolism of microorganisms (Nies et al., 1999). The availability of this metal helps in degrading waste canola oil as the bacterial community was able to resist and survive. Zhou et al. (2013) reported that in the presence of $\mathrm{Co}$, as a catalyst, to the bicarbonate-activated $\mathrm{H}_{2} \mathrm{O}_{2}$ accelerated the degradation rate of dyes and phenol.

Growth kinetic modelling is a useful tool in implementation for process control and field-scale bioremediation designs. The effects of heavy metals in bacterial growth in biodegrading pollutants are among the important environmental factors that may be affect the bioremediation process since the availability of heavy metals are found in the environment either from natural sources or anthropogenic activities. From this study, the microbial growth profile was regressed using exponential and linear models, which allowed the prediction of microbial growth behaviour by knowing the kinetic parameters including growth rate, doubling time and best-fitting models. The parameters for goodness of the curve for exponential regression curve fit were shown, including the coefficient determination $\left(R^{2}\right)$, degree of freedom (DF), as well as the sum of squares (SS) and standard deviation of the residuals (Sy.x). The $\mathrm{R}^{2}$ value allowed to compare the fit of the model to fit an experimental line through means of all $Y$-axis values. $A$ high $R^{2}$ value indicates that the curve of regression was close to the experimental value, and the possibilities for the curve to the best fit were high. The result exhibited the highest $R^{2}$ value of $\mathrm{Ni}$ at 0.8421 , followed by $\mathrm{Cr}$ and $\mathrm{Zn}$ at 0.825 and 0.8005 , respectively. However, the value of SS and sy.x both for $\mathrm{Ni}$ and $\mathrm{Cr}$ were higher as compared to $\mathrm{Zn}$ (SS: 2.057; Sy.x: 0.3058). The low value of SS shows the regression curve minuses the SS of the distance of the points from the curve, while Sy. $x$ value is the standard deviation of the vertical distances of the experimental point from the regressed line. Ideally, the SS and sy.x values should be lower in any regression model, which indicates a fitted model to the data.

The non-linear regression graph showed different $Y_{0}$, as the presence of a different type of heavy metals affected the growth pattern of BS14 (Fig. 2), while k is the rate constant. All data were regressed with the exponential growth equation, where $Y_{0}$ also could be observed from the graph, as shown in Fig. 2; at the same time, the best-fit values were determined during the analysis (Table 2). This parameter value was found within the $95 \%$ confidence interval of distribution as it indicated the best-fit values for the growth curve of the bacteria. $Y_{0}$ is the turbidity of cells when time is zero, while $T_{d}$ is the doubling period, which is a process that gives rise to significant cells to double in size or value at a certain time especially in lag phase for bacterial growth curve (Todar, 2012). The value of $Y_{0}$ for the bacterial growth in the presence of $\mathrm{Ni}, \mathrm{Cr}$ and $\mathrm{Co}$ was low in value and offered faster doubling time i.e., $61.27,65.45,71.31 \mathrm{~h}$ for $\mathrm{Ni}, \mathrm{Cr}$ and $\mathrm{Co}$,respectively. Meanwhile, the bacteria community required more time for their population to double in number in $\mathrm{Al}(104.2 \mathrm{~h})$ and $\mathrm{Cd}$ 
K.N.M. Zahri et al.: Metal-tolerant waste canola oil-degrading bacteria
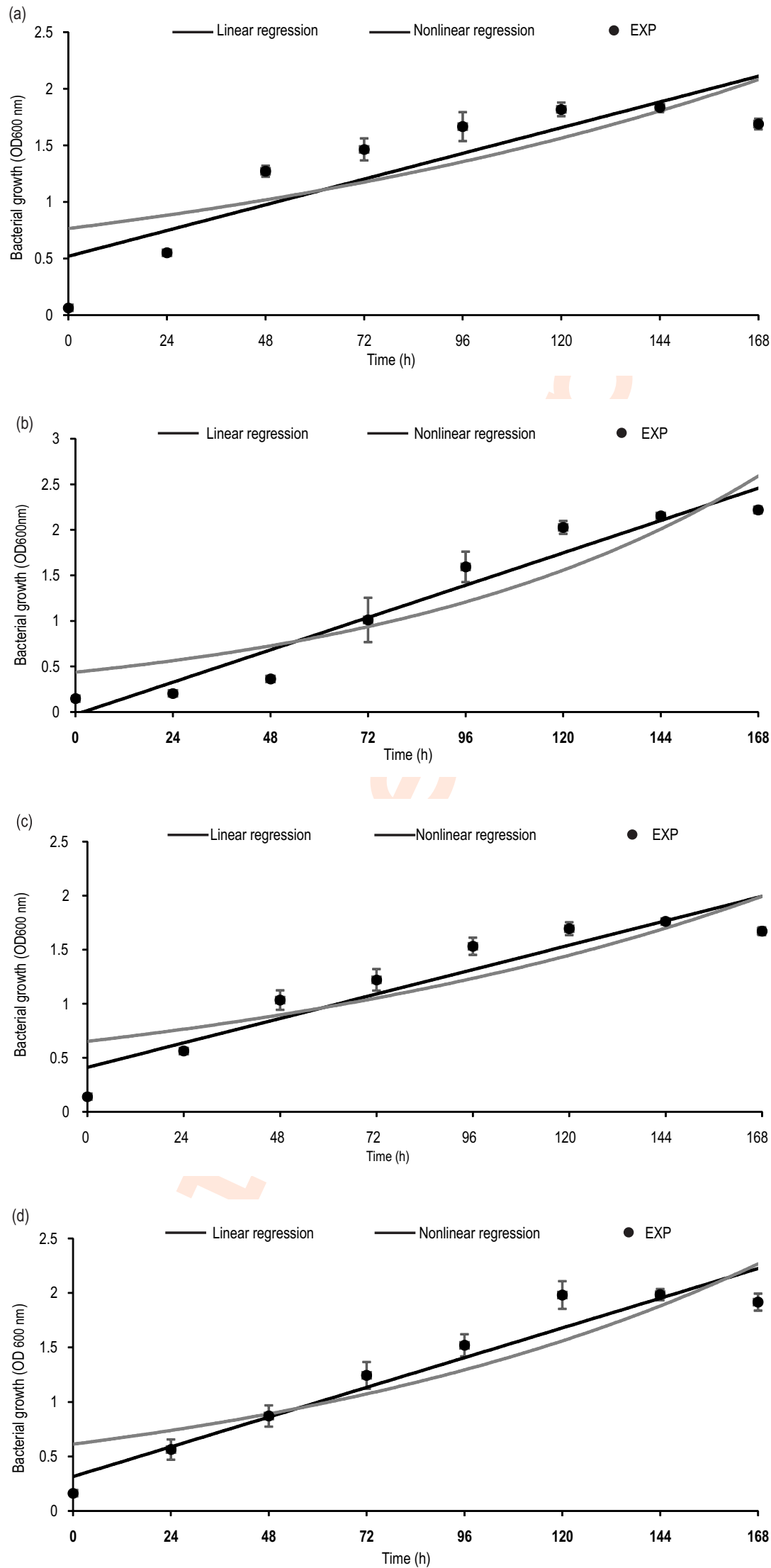

- Journal of Environmental Biology, November 2020 

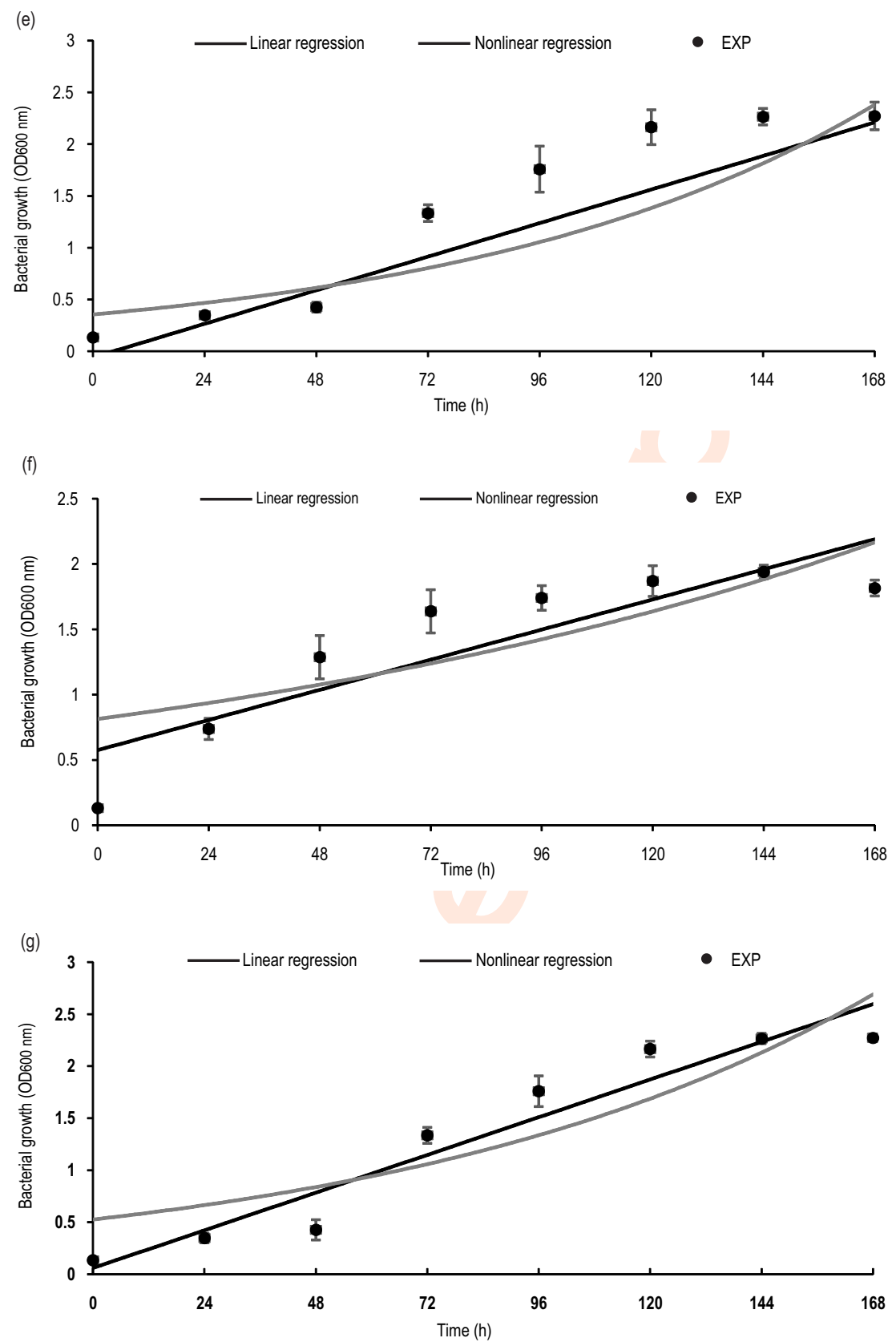

Fig. 2: Exponential regression model. (a) Cadmium. (b) Chromium. (c) Aluminium. (d) Zinc (e) Nickel. (f) Arsenic and (g) Cobalt. EXP indicate to experimental data. Data represent mean $\pm \operatorname{SEM}(n-3)$.

(116.4 h) media. The slower $T_{d}$ may have caused the bacterial to grow and degrade at a lower percentage at the end of incubation time (Fig. 1). Generally, low $T_{d}$ value will exhibit a high rate of bacterial growth ( $k$ ) under any circumstances.

The $\mathrm{k}$ value is the rate constant, also known as the maximum specific substrate rate (Talaiekhozani et al., 2015). The rate constant can be expressed through the relationship between the rate of a reaction (growth of bacterial) and the concentration of reacting substance (heavy metals). According to Table 2, the availability of nickel shown the highest rate constant at $0.01131 \mathrm{~h}$ ${ }^{1}$, and this revealed the reaction is faster as compared to other condition. This exhibits the reasons for doubling time for the bacteria in the presence of nickel is fast (low in value). Simultaneously, the low rate constant indicates slow reaction, for instance, the bacteria in the $\mathrm{Cd}$ and As medium at 0.005957 and 
Table 1: ANOVA table (goodness of fit) for exponential regression curve fit of BS14 consortium in a different type of heavy metals availability

\begin{tabular}{lllll}
\hline \multirow{2}{*}{ Heavy metals } & \multicolumn{4}{l}{ Goodness of fit } \\
\cline { 2 - 5 } & $\mathbf{R}^{2}$ & DF & SS & Sy.x \\
\hline Cadmium & 0.6396 & 22 & 3.059 & 0.3729 \\
Chromium & 0.825 & 22 & 3.016 & 0.3703 \\
Aluminium & 0.7402 & 22 & 1.936 & 0.2967 \\
Zinc & 0.8005 & 22 & 2.057 & 0.3058 \\
Nickel & 0.8421 & 22 & 2.309 & 0.324 \\
Arsenic & 0.6365 & 22 & 3.226 & 0.3829 \\
Cobalt & 0.7964 & 22 & 3.712 & 0.4107 \\
\hline
\end{tabular}

Abbreviation: Degree of freedom (DF), Coefficient determination $\left(R^{2}\right)$, sum of squares (SS), standard deviation of the residuals (Sy.X)

Table 2: ANOVA table (best-fit values) for exponential regression curve fit of BS14 consortium in a different type of heavy metals availability

\begin{tabular}{llll}
\hline & & Best-fit values & \\
\cline { 2 - 4 } Heavy metals & $\mathbf{Y}_{0}(\mathbf{n m})$ & $\mathbf{D T}(\mathbf{h})$ & $\mathbf{k}\left(\mathbf{h}^{-1}\right)$ \\
\hline Cadmium & 0.7654 & 116.4 & 0.005957 \\
Chromium & 0.4371 & 65.45 & 0.01059 \\
Aluminium & 0.6522 & 104.2 & 0.006653 \\
Zinc & 0.6125 & 88.98 & 0.00779 \\
Nickel & 0.3561 & 61.27 & 0.01131 \\
Arsenic & 0.8136 & 119 & 0.005827 \\
Cobalt & 0.5256 & 71.31 & 0.00972 \\
\hline
\end{tabular}

Abbreviation: Initial concentration $\left(\mathrm{Y}_{0}\right)$, doubling time $(\mathrm{T})$, rate constant $(\mathrm{k})$

Table 3: ANOVA table for linear regression curve fit of BS14 consortium in a different type of heavy metals availability

\begin{tabular}{lllll}
\hline Heavy metals & $\mathbf{R}^{2}$ & Sy.x & $\mathbf{F}$ & $\mathbf{k}\left(\mathbf{h}^{-1}\right)$ \\
\hline Cadmium & 0.7666 & 0.3001 & 72.26 & 0.009469 \\
Chromium & 0.921 & 0.2488 & 256.4 & 0.01479 \\
Aluminium & 0.8631 & 0.2154 & 138.7 & 0.009414 \\
Zinc & 0.9082 & 0.2075 & 217.6 & 0.01136 \\
Nickel & 0.9062 & 0.2497 & 212.5 & 0.01351 \\
Arsenic & 0.7554 & 0.3141 & 67.93 & 0.009610 \\
Cobalt & 0.9082 & 0.2758 & 217.7 & 0.01510 \\
\hline
\end{tabular}

Abbreviation: Coefficient determination $\left(R^{2}\right)$, standard deviation of the residuals (Sy.x), F-value (F), rate constant $(k)$

$0.005827 \mathrm{~h}^{-1}$, respectively. The growth rates can be arranged in the decreasing order of $\mathrm{Ni}>\mathrm{Cr}>\mathrm{Co}>\mathrm{Zn}>\mathrm{Al}>\mathrm{Cd}>\mathrm{As}$.

On the other hand, linear regression also was observed in this study. Linear regression fits a straight line through the experimental data to find the best-fit value of the slope and intercept. According to Fig. 2, the bacterial growth for BS14 with Zn (Fig. 2d) showed the best fitted model as compared to others. The value $R^{2}(0.9082)$ values was high while sy. $x$ value, was low (0.2075). This can be considered that the growth pattern of bacteria in the presence of $\mathrm{Zn}$ shows as a good model. Although $\mathrm{Cr}$ displayed the highest $\mathrm{R}^{2}$ value at 0.921 , the error of the regressed line was high (0.2488). The rate constant $(k)$ of this regression curve can be arranged in decreasing order of $\mathrm{C}_{0}>$ $\mathrm{Cr}>\mathrm{Ni}>\mathrm{Zn}>\mathrm{As}>\mathrm{Cd}>\mathrm{Al}$, where the highest growth kinetic rate was at $0.01510 \mathrm{~h}^{-1}$ in Co media. Yet, the bacterial growth in the availability of $\mathrm{Zn}$ exhibited the growth rate at $0.1136 \mathrm{~h}^{-1}$, which is considered to be in a high range of growth rate. F-value is an important kinetic parameter for the determination of best-fitted data to the kinetics equation as $F$ value indicates whether or not the linear regression model provides a better fit to the data. The analysis of linear regression also shows 95\% confidence interval for the slope. All media with a different type of heavy metals used in this study fell on the range of $95 \%$ confidence 
interval. This range value of the slope contain true value of the slope, and the width of the confidence intervals was determined by the number of data points (GraphPad, 2007).

The results of this study suggested that each of the heavy metals affected the growth of bacteria and were able to inhibit or stimulate waste canola oil degradation. Each growth curve can perform different regression fit with different best-fit values for the results as presence of heavy metals changes the behaviour of cell bacterial growth. The obtained results for different growth kinetic regression curves indicate that linear regression curves can better understand the growth kinetics of Antarctic bacterial community with faster rate of bacterial growth, high values of $R^{2}$ and low values of error. These kinetics parameters are important in understanding the biodegradation process, including measuring the speed of bioremediation and improvement of efficient clean up for a waste oil contaminated environment.

\section{Acknowledgments}

This work was supported by Universiti Putra Malaysia (Matching Grant PUTRA (9300436) and PUTRA Berimpak (9678900), Yayasan Penyelidikan Antartika Sultan Mizan (YPASM- Smart Partnership Initiative) and Centro de Investigacion y Monitoreo Ambiental Antártico (CIMAA). The authors would like to thanks Chilean scientist Nancy Calisto-Ulloa from Universidad de Magallanes, Chile and Nicolás RamírezMoreno from Pontificia Universidad Católica de Valparaíso, Chile for their previously help.The authors also would like to thanks Chilean Army and the Antarctic General Bernardo O'Higgins Station staff especially the Comandante de la Base O'Higgins; Teniente CoronelJose Ignacio Alvarado Camps, the Comandante de la sección de exploracion y rescate O'higgins; Capitan René Salgado Rebolledo and the staff; especially the Chef; Suboficial Juan David Sandoval Navarrete and Sargento Juan Eduardo Cortínez Padovani; Sargento Segundo Augusto Antonio Barra Morale, Sargento Segundo Flavio Marcelo Nahuelcoy Perez, and Sargento Segundo Claudio Durand Ibacache.

\section{References}

Abatenh, E., B. Gizaw, Z. Tsegaye and M. Wassie: The role of microorganisms in bioremediation- A review. J. Environ. Biol., 1, 38-46 (2017).

Abbas, S.Z., M. Rafatullah, N. Ismail and J. Lalung: Isolation, identification and characterization of cadmium resistant Pseudomonas sp. M3 from industrial wastewater. J. Waste Manag., 2014, DOl 10.1155/2014/160398 (2014).

Abdu, N., A.A. Abdullah and A. Abdulkadir: Heavy metals and soil microbes. Environ. Chem. Lett., 15, 65-84 (2016).

Aislabie, J., R. Fraser, S. Duncan and R.L. Farrell: Effects of oil spills on microbial heterotrophs in Antarctic soils. Polar Biol., 24, 308-313 (2001).

Al-Hadithi, H.T., E.A. Al-Razzaq and G.F. Fadhil: Bioremediation of polycyclic aromatic hydrocarbons by Acinetobacter species isolated from ecological sources. J. Environ. Biol., 38, 785-789 (2017).

Brooksbank, A.M., J.W. Latchford and S.M. Mudge: Degradation and modification of fats, oils and grease by commercial microbial supplements. World J. Microb. Biot., 23, 977-895 (2007).

Bruins, M.R.M., S.K. Kapil and F.W. Oehme: Microbial resistance to metals in the environment. Ecotoxicol. Environ. Saf., 45, 198-207 (2000).

Chu, W., N. Dand, Y. Kok, K. Yap, S. Phang and P. Convey: Heavy metal pollution in Antarctica and its potential impacts on algae. Polar Sci., 20,75-83 (2019).

Department of Ecology: Spill prevention, preparedness and response program. Retrieved from www.ecy.wa.gov/biblio/96250.html (2016).

Falade, A.O., G. Oboh and A.I. Okoh: Potential health implications of the consumption of thermally-oxidised cooking oils- A review. Pol. J. Food Nutr. Sci., 67, 95-105 (2017).

García-Dávila, J., E. Ocaranza-Sánchez, C. Sánchez, E. OrtegaSánchez, S. Tlecuitl- Beristaín and A.L. Martínez-Ayala: FTIR analysis of hydrotreated Jatropha curcas L. seed oil over ni-mo catalyst for biofuel production. Rev. Mex. Ing. Quím., 16, 337-345 (2017).

GraphPad Software: Principles of regression. Retrieved from www.graphpad.com (2007).

Gupta, P.K. and B.K. Yadav: Bioremediation of non-aqueous phase liquids (NAPLs) polluted soil and water resources Chapter 8. In: Environmental Pollutants and their Bioremediation Approaches (Ed.: R.N. Bharagava). CRC Press, Boca Raton (2017).

Hall, B.G., H. Acar, A. Nandipati and M. Barlow: Growth rates made easy. Mol. Biol. Evol., 31, 232-238 (2003).

Henning, R.J., G.T. Johnson, J.P. Coyle and R.D. Harbison: Acrolein can cause cardiovascular disease: A review. Cardiovasc. Toxicol., 17, 227-236 (2017).

Hughes, K.A., O.L. Pescott, J. Peyton, T. Adriaens, E.J. Cottier-Cook, G. key, W. Rabitsch, E. Tricarico, D.K.A. Barnes, N. Baxter, M. Belchier, D. Blake, P. Convey, W. Sawson, D. Frohlich, L.M. Gardiner, P. Gonzalez-Moreno, R. James, C. Malumphy, S. Martin, A.F. Martinou, D. Minchin, A. Monaco, N. Moore, S.A. Morley, K. Ross, J. Shanklin, K. Turkey, D. Vaughan, A.G.C. Vaux, V. Werenkraut, I.J. Winfield and H.E. Roy: Invansive non-native species likely to threaten biodiversity and ecosystem in the Antarctic Peninsula region. Glob. Change Biol., 26, 2702-2716 (2020).

Ibrahim, S., A. Zulkharnain, K.N.M. Zahri, G.L.Y. Lee, P. Convey, C. Gomez-Fuentes, S. Sabri, K.A. Khalil, S.A. Alias, G. GonzalesRocha and S.A. Ahmad: Effect of heavy metals and other xenobiotics on biodegradation of waste canola oil by cold-adapted Rhodococcus sp. strain AQ5-07. Rev. Mex. Ing. Quím., 19, 10411052 (2020).

Igiri, B.E., S.I.R. Okoduwa, G.O. Idoko, E.P. Akabuogu, A.O. Adeyi and I.K. Ejiogu: Toxicity and bioremediation of heavy metals contaminated ecosystem from tannery wastewater: A review. J. Toxicol., 18, DOI 10.1155/2018/2568038 (2018).

Karaca, A., S.C. Cetin, O.C. Turgay and R. Kizilkaya: Effects of heavy metals on soil enzyme activities. In: Soil Heavy Metals. Soil Biol., $19,237-262(2010)$.

Kim, D.J., J.W. Choi, N.C. Choi, B. Mahendran and C.E. Lee: Modeling of growth kinetics for Pseudomonas spp. during benzene degradation. Appl. Microbiol. Biotechnol., 69, 459-462 (2005).

Kurniawan, S.B., I.F. Purwanti and H.S. Titah: The effect of $\mathrm{pH}$ and aluminium to bacteria isolated from aluminium recycling industry. J. Ecol. Eng., 19, 154-161 (2018).

Lee, G.L.Y., S.A. Ahmad, N.A. Yasid, A. Zulkharnain, P. Convey, W.L.W. Johari, S.A. Alias, G. Gonzalez-Rocha and M.Y. Shukor: Biodegradation of phenol by cold-adapted bacteria from Antarctic soils. Polar Biol., 41, 553-562 (2018). 
Malley, C., J. Nair and G. Ho: Impact of heavy metals on enzymatic activity of substrate and on composting worms Eisenia fetida. Biosour. Technol., 97, 1498-1502 (2006).

Martínez-Prado, M. and C. Soto-Álvarez: Removal of petroleum hydrocarbons from a low permeability soil: Bioremediation and electroremediation. Rev. Mexi. Ing. Quím., 16, 955-970 (2017).

Murthy, S., G. Bali and S.K. Sarangi: Effect of lead on growth, protein and biosorption capacity of Bacillus cereus isolated from industrial effluent. J. Environ. Biol., 35, 407-411 (2014).

Neto, E.L., M.B.B. Guerra, A. Thomazini, D.M. Mayara, de Andrade and C.E.G.R. Schaefer: Soil contamination by toxic metals near an Antarctic refuge in Robert Island, Maritime Antarctica: Amonitoring strategy. Water Air Soil Pollut., 228, DOI 10.1007/s11270-0173245-4 (2017).

Niess, D.H.: Microbial heavy-metal resistance. Appl. Microbiol. Biotechnol., 51, 730-750 (1999).

Pandey, S., P. Saha, S. Biswas and T.K. Maiti: Characterisation of two metal resistant Bacillus strains isolated from slag disposal site at Burnpur, India. J. Environ. Biol., 32, 773-779 (2011).

Purwanti, I.F., D.Y. Simanjuntak and S.B. Kurniawan: Toxicity test of aluminium to Vibrio alginolyticus as a preliminary test of contaminated soil remediation. AIP Conference Proceedings 2049, 020030, DOI 10.1063/1.5082435 (2018).

Roslee, A.F.A., N.N. Zakaria, P. Convey, A. Zulkharnain, G.L.Y. Lee, C. Gomez-Fuentes and S.A. Ahmad: Statistical optimisation of growth conditions and diesel degradation by the Antarctic bacterium, Rhodococcus sp. strain AQ5-07. Extremophiles, 24, 277-291 (2019).

Ruberto, L., S. Vazquez, A. Lobalbo and W.P.M. Cormack: Psychrotolerant hydrocarbon-degrading Rhodococcus strains isolated from polluted Antarctic soils. Antarct. Sci., 17, 47-56 (2005).

Samimi, M. and M. Moghadam: Phenol biodegradation by bacterial strain $\mathrm{O}-\mathrm{CH} 1$ isolated from seashore. Global J. Environ. Sci. Manage., 6, 109-118 (2020).

Sandrin, T.R. and R.M. Maier: Impact of metals on the biodegradation of organic pollutants. Environ. Hlth. Perspect., 111, 1093-1101 (2003).

Talaiekhozani, A., N. Jafarzadeh, M.A. Fulazzaky, M.R. Talaie and M. Beheshti: Kinetics of substrate utilisation and bacterial growth of crude oil degraded by Pseudomonas aeruginosa. J. Environ. Hlth. Sci., 13, DOI 10.1186/s40201-015-0221-z (2015).

Todar, K.: The growth of bacterial populations. Todar's Online Textbook of Bacteriology. Retrieved from www.textbookbacteriology.net (2012).

Zahri, K.N.M., A. Zulkharnain, S. Ibrahim, C. Gomez-Fuentes, S. Sabri, N. Calisto-Uloa and S.A. Ahmad: Kinetic analysis on the effects of lead $(\mathrm{Pb})$ and silver on waste canola oil (WCO) biodegradation by selected Antarctic microbial consortium. Malaysia J. Biochem. Mol. Biol., 23, 20-23 (2020).

Zakaria, N.N., A.F.A. Roslee, C. Gomez-Fuentes, A. Zulkharnain, M. Abdulrasheed, S. Sabri, N. Ramirez-Moreno and S.A. Ahmad: Kinetic studies of marine psychrotolerant microorganisms capable of degrading diesel in the presence of heavy metals. Rev. Mex. Ing. Quím., 19, 1375-1388 (2020).

Zhou, L., W. Song, Z. Chen and G. Yin: Degradation of organic pollutants in wastewater by bicarbonate-activated hydrogen peroxide with a supported cobalt catalysts. Environ. Sci. Tech., 47, 3833-3839 (2013). 